\author{
Magdalena Ratajczak \\ Uniwersytet Wrocławski \\ ORCID: 0000-0002-6922-1317
}

\title{
The media image of "solidarity" in the crisis
}

\begin{abstract}
This article describes the narratives about refugees and migrants as well as information about the COVID-19 pandemic, in the context of mutual understanding, solidarity with others, community-building in a crisis, all presented through the media of photographs. This article is the result of an analysis of visual images on the internet. These two crises reveal different attitudes to solidarity in Europe, both among the citizens as well as politicians of different countries.
\end{abstract}

Keywords: solidarity, COVID-19, migration crisis.

\section{Medialny obraz „solidarności” w czasach kryzysu}

Streszczenie

Artykuł poświęcono narracji o uchodźcach i migrantach oraz informouaniu o pandemii COVID-19 u kontekście wzajemnego zrozumienia, solidarności z innymi, tworzenia uspólnoty w kryzysie, prezentowanej poprzez zdjęcia. Stanowi wynik analizy treści wizualnych w internecie. Te dwa uydarzenia kryzysowe obrazują u Europie nieco odmienne podejścia do solidarności, zaróuno na poziomie obywateli, jak i polityków oraz poszczególnych państw.

Słowa kluczowe: solidarność, COVID-19, kryzys migracyjny.

\section{The power of the photographic image in the crisis}

Contemporary states face crises increasingly often. This term does not only apply to economic crises, but also those brought about by politicians, leaders or outside factors, such as natural disasters or epidemics. Crises tend to be widely commented on in the media. The world faces various crises, which affect particular regions (continents) or are more global in nature, such as the recent economic crisis, the migration crisis that started in 2015 or the current COVID-19 pandemic, started in 2020. Migrations and the pandemic have become an important element of discourse in the media. It is partly through the migration crisis and then, to a fuller extent the COVID-19 pandemic, that use and frequency of use of the media has changed.

Globally speaking, the early months of the pandemic saw a dramatic increase in the amount of time people spent accessing information about current events. A June 2020 report from data analytics company Nielsen found that in March 2020 individuals 
in the US spent $215 \%$ more time reading news online relative to the same month last year. This figure was 180\% in Italy, 125\% in Thailand, 78\% in Japan and 52\% in Australia ${ }^{1}$.

During the crisis there was an increase in the level of interest in crisis-related items of information. Research shous that there was not only a noticeable increase in interest in news sites but also social media networks. This increase in activity on the net is also connected with changes in lifestyle and work patterns. The lockdowns, as well as online work and study significantly changed the use of the media.

This article describes the narratives about refugees and migrants as well as information about the COVID-19 pandemic, in the context of mutual understanding, solidarity with others, community-building in a crisis, all presented through the media of photographs.

I have studied the subject of refugees and migrants in the media for a number of years using various research methods. This article is the result of an analysis of visual images on the internet. I have posed the question as to what extent do the images taken during the migrant crisis and the COVID-19 pandemic shape or create the discourse supporting such notions as solidarity, understanding others, community or helping others? According to Piotr Cichocki, Tomasz Jędrkiewicz and Robert Zydel,

the internet knows no geographic borders, the notion of distance is practically non-existent and everything is within the reach of our hand or cursor. Despite this it has become accepted that the metaphor of space should be used in describing the net. This is a space we surf through, where we experience adventures and where we gain experience and, most importantly, meet 'the Others'.

The internet gives a sense of participation in events that take place hundreds of kilometres away.

Photographic images play a particular role here. In analysing media discourse taking into account the categories of solidarity and community in the case of these two crises, I selected 80 photographs (40 making reference to the migrant crisis and 40 portraying COVID-19). The photographs related to the migrant crisis cover the period between 1 January 2015 and 31 December 2016. The photographs focused on the health crisis refer to the period between 1 February 2020 and 28 February 2021. The selection of images was linked to such as categories: migration, refugees, COVID-19, solidarity, compassion, drama, loneliness, aid, cultural difference. All the images were internet-sourced and were taken by media photographers (from various Polish, English, German, French, Italian, Spanish and Swiss publications) in Europe. I selected photographs from private and public service media. Writing

\footnotetext{
${ }^{1}$ Navigating the challenges of digital advertising during a global pandemic, https://www. nielsen.com/us/en/insights/article/2020/navigating-the-challenges-of-digital-advertising-during-a-global-pandemic/ (accessed: 12.01.2021).

2 P. Cichocki, T. Jędrkiewicz, R. Zydel, Etnografia wirtualna [in:] Badania jakościowe. Metody i narzędzia, Vol. 2, ed. D. Jemielniak, Wydawnictuo Naukowe PWN, Warszawa 2012, p. 205.
} 
about the significance of the photographic image I drew on the book by Roland Barthes who made the distinction between two types of photographs ${ }^{3}$. He termed the first as a 'study'. These photographs capture a moment in time portraying a journey that may be significant or a family meeting. For Barthes the photographs that fall into the second category, which he termed 'punctum' are far more significant. He does not define them precisely, choosing instead a metaphorical description as a 'sting, hole, small stain, small incision - but also a roll of the dice'. This plays the decisive role in causing a photograph thus defined to become ingrained in the memory of the person looking at it, remaining with him longer and drawing his attention with particular impact. I have chosen for analysis the photographs, which in my subjective opinion, combine the 'studium' and 'punctum' elements. They, on the one hand portray a particular event but next, also impact on the recipient and aim to have a longer impact. The pictures selected often show individuals unknown to us and the problems they face but are aimed at building a feeling of community and understanding.

As Jolanta Maćkiewicz notes,

Undoubtedly images have the function of drawing attention. In a verbal and image communication, be that an advertisement, the front page of a newspaper or a television news programme, first (as has been proved by research findings) our attention is drawn to the image. In addition those words that are written into the picture and are graphically integrated with it, such as a headline or lead placed on a press photograph, attract greater attention. Moreover images have a greater impact on emotions than words as has been widely researched ${ }^{4}$.

According to the author this is impact through their vivid and expressive nature and they thus have a greater and more immediate impact. Thanks to this they evoke different associations and are able to reach recipients with different visual competence and different experience ${ }^{5}$.

This text has partly used visual ethnography, which

transported into the online world, using off-line tools, such as an interview, participant and non-participant observation, makes it possible to use one-off, incidental experiences into a systematized cognitive mechanism revealing both the 'Outsider' as well as ourselves ${ }^{6}$.

This article has also employed visual anthropology. I am treating photographs as a "record concerning culture". A picture is the tool that constructs a description of reality, which in the case of this article jointly creates a feeling of solidarity and community.

${ }^{3}$ R. Barthes, Światto obrazu. Uwagi o fotografii, transl. J. Trznadel, Wydaunictwo KR, Warszawa 1996.

4 J. Maćkiewicz, Więcej niż tysiąc słów. Perswazyjne działanie zdjęć prasowych, „Media Biznes - Kultura" 2018, No. 1(4), p. 26.

${ }^{5}$ Ibidem.

${ }^{6}$ P. Cichocki, T. Jędrkiewicz, R. Zydel, Etnografia wizualna..., p. 205. 


\section{Diversity in solidarity?}

European solidarity can take place on several levels (local, regional, national, EU) and may refer to different actors expressing solidarity, including citizens, politicians, institutions and member states ${ }^{7}$. But only few studies have investigated the extent to which attitudes towards European solidarity are influenced by information ${ }^{8}$. Andreas C. Goldberg, Katjana Gattermann, Franziska Marquart, Anna Brosius, Claes de Vreese argue that,

in times of crisis, these factors are particularly important for two reasons: first, given the extraordinary scale of the pandemic, the information supply is rapid and dense, which makes it difficult to follow even for journalists and policy-makers, let alone European citizens. Likewise, media frames of solidarity may change quickly and may even evolve concurrently in short periods of time. Second, and related, citizens are actively seeking out information and therefore turn to traditional and social media9.

The authors therefore expect that information and media use play a crucial role in the preference formation of citizens towards European solidarity over the course of the crisis. The European Broadcasting Union reported that during the first weeks of the COVID-19 pandemic, public broadcasting news programmes saw a surge in audience numbers across Europe, and overall news use increased substantially in the early stages of the pandemic ${ }^{10}$.

These two crises reveal different attitudes to solidarity in Europe, both among the citizens as well as politicians of different countries. The migrant crisis divided Europeans (governments and citizens) into those who took real steps to deal with the presence of migrants and refugees and those who were against accepting them. In the first group were countries from the south of Europe, especially Italy, Greece and Spain and western European countries with Germany, Austria, France and Scandinavian countries foremost among them. In the latter group were mostly countries from the Vyshehrad Group, especially Poland and Hungary.

\footnotetext{
7 A.C. Goldberg, K. Gattermann, F. Marquart, A. Brosius, C.H. de Vreese, European solidarity in times of crisis: the role of information and media use, „West European Politics”, 2021, Vol. 44(5-6), pp. 1-12. See more: I. Ciornei, E. Recchi, At the Source of European Solidarity: Assessing the Effects of Cross-Border Practices and Political Attitudes, „Journal of Common Market Studies” 2017, Vol. 55, Issue 3, pp. 468-485; Solidarity in Europe: Citizens' Responses in Times of Crisis, eds. Ch. Lahusen, M.T. Grasso, Palgrave Macmillan, London 2018.

8 V.K. Brandle, O. Eisele, Sharing Is Caring? Exploring the Relationship between Preferences for Online Participation and Support for Solidarity between EU Member States, „American Behavioral Scientist" 2019, Vol. 63, No. 4, pp. 523-537.

${ }^{9}$ A.C. Goldberg, K. Gattermann, F. Marquart, A. Brosius, C.H. de Vreese, European solidarity in times of crisis..., p. 3.

${ }^{10}$ European Broadcasting Union 2020. Public Service Media are Trusted Sources of Information on COVID-19 Crisis, https://wuw.ebu.ch/news/2020/03/public-service-media-are-trusted-source-of-information-on-COVID-19-crisis-1 (accessed: 21.02.2021).
} 
For sure it was a new experience for everyone. The media showed crowds of non-Europeans who, for different reasons, wanted to come to Europe. According to Agnieszka Całek,

the eruption of the migrant crisis in Europe showed that the Others became present in the mainstream media, on an unprecedented (hitherto) scale. Earlier the Others or Outsiders were present, principally in travel-related media. Distant, exotic and non-threatening. It was not he, who came to Europe but rather Europeans visited him for a short while in the safe position of a tourist. This often did not even entail the need to enter into a dialogue or interact in any way as these tasks were carried out by the tour operator's employees ${ }^{11}$.

Of course, the experiences with the 'Others' were very different from country to country. Great Britain, Germany or Sueden had earlier experience of an influx of migrants, who were principally economic migrants. Countries, such as Poland, Hungary or the Czech Republic did not have such experiences. The Poles, for example, had dealt with economic migrants from Ukraine and in the 1990s with a large group of Chechen refugees. These different experiences, particularly of countries from the south, meant that European solidarity was not awakened automatically with the appearance of the new arrivals on the Mediterranean. Appeals to solidarity, understanding of others and greater empathy cropped up in dialogue but not as often as the problem of migration. The word 'problem' took on a key importance and meant that Europeans began to view the events from this negative perspective. Norman Davies in 2015 reminded us that in the past migrations had been the norm in Europe. The structure of Europe, as well as other continents is the result of migration.

The migration crisis that started in 2015 posed a challenge to Europeans, but also became a social, political and economic problem. The UN compares the current migrations to those of the II WW era. Global forced displacement has increased in 2015, with record-high numbers. By the end of the year, 65.3 million individuals were forcibly displaced worldwide as a result of persecution, conflict, generalized violence, or human rights violations. This is 5.8 million more than the previous year (59.5 million) ${ }^{12}$.

According to Helene Thiollet, ,"The perception that migration is on the rise, is often connected with a long-lasting cumulation of waves of migration. There is also the fact that some migrants are particularly 'noticeable' and they attract media and political attention as well as becoming a bargaining chip in election campaigns and ideological projects" ${ }^{\prime 3}$. The proof lies in the numbers. Out of the 3.4 million immigrants in Europe 1.2 million are Europeans. It is the immigrants from North and Sub-Saharan Africa that attract media attention, however. In this group there are both economic migrants as well as refugees escaping from war. Unfortunately political and media debate has

\footnotetext{
11 A. Całek, Wojciech Tochman - społeczny rzecznik uchodźców. Zapiski z obserwacji netnograficznej, „Media - Biznes - Kultura” 2018, No. 1(4), p. 71.

${ }_{12}$ Global Trends Forced Displacement in 2015, http://www.unhcr.org (accessed: 22.02.2021).

${ }^{13}$ Migranci, migracje. O czym warto wiedzieć, by wyrobić sobie własne zdanie, ed. H. Thiollet, Karakter, Kraków 2017, p. 11.
} 
meant that Europeans often fail to make this distinction. A person who is a refugee is often confused with a migrant and each one is portrayed in the category of risk.

It is worth referring to quotes by Norman Davies who thinks that a fear of Islam, which has become so common recently, often appears even before these people make an appearance on our streets. According to Davies this is often the 'achievement' of television and the internet which show crowds of people forcing their way through borders, with crowded trains and camps. "This is only a fragment of the reality. These days the media have a great responsibility. Depending on whether they speak of people 'besieging the continent' or of those 'escaping murderous regimes' the reaction of Europeans will be influenced"14. Davies also places great responsibility on politicians. It is the media and the politicians in the media who represented images of refugees and migrants employing metaphors as rhetorical devices to describe these people and their problems. The water metaphor is very well-known. The refugees and migrants, without differentiating between them, are portrayed as a flood, wave or tide. These types of expressions usually are connected with phenomena beyond our control but they are synonymous with disaster and forces that are difficult to stop. In short phenomena that we have no control over.

The metaphor of disease - both physical and psychiatric, also dominated. The refugees were presented as a potential health hazard for Europeans, potentially spreading dangerous diseases. On the other those who declared help for the refugees were accused of wanting to destroy Europe or of 'suicide' for the continent. This appears particularly relevant in the dehumanizing process. Terms, such as 'beasts', 'barbarians' or 'wild people' were used ${ }^{15}$.

It is clear that the rhetoric of war was also very important. The media used such terms as 'invasion', 'attack', 'conquest' or even 'war' to heighten the feeling of threat and danger.

On the other side we could see pro-refugee discourse, which made appeal to such notions as 'solidarity' or 'community.

The COVID-19 pandemic has a rather different dimension. In this case solidarity took on a different experience. In Europe Italy was the first country to experience the pandemic on a scale which was a totally surprising and incomprehensible phenomenon for Europeans. Europe remained passive in the face of what was happening in Italy, believing that the virus would not cross the borders of other countries on such a scale. The Italian media asked about European solidarity, with a feeling of isolation in the face of such a great tragedy of its citizens.

It was not until on 16th of April European Commission President Ursula von der Leyen in a speech to the European Parliament apologized to Italy on behalf of Europe for its failure to do more to help at the start of the coronavirus pandemic. "It is true that

${ }_{14}$ Lekcje z historii, rozmowa Marcina Żyty z Normanem Daviesem, „Tygodnik Pouszechny”, 20.09.2017, pp. 11-12.

${ }^{15}$ M. Ratajczak, K. Jędrzejczyk-Kuliniak, Muslims and Refugees in the Media in Poland, „Global Media Journal” 2016, Vol. 6, No. 1. 
no one was really ready for this. It is also true that too many were not there on time when Italy a needed a helping hand at the very beginning" 16.

The significance of solidarity during the COVID-19 pandemic has two main dimensions and a third, peripheral one. The first is solidarity with health service workers. Images of exhausted doctors, nurses and diagnostic technicians have become symbols of the pandemic. Words of support for them, demonstrations of solidarity with them or tangible help (such as restaurants which offered meals) were treated by the media with particular sensitivity. The media also sent messages of support and solidarity for the families of health service workers, particularly those who had lost family members as a result of COVID-19. The second dimension is solidarity with the sick. Images of crowded hospitals, temporary hospitals, stories told by their families reinforced a certain community of the sick and those affected by the pandemic in different ways.

The third, which I termed as peripheral was not present in the main media coverage. One of the pictures I have chosen illustrates this problem. This is concerned with solidarity with the homeless, refugees during the pandemic. Barely noticeable in the media but, paradoxically, these two crises in some ways overlapped. What can serve as an example is overcrouded refugee camps or the homeless on the streets of large cities.

\section{Images of hope and solidarity}

Both pro and anti-refugee discourse was present in the majority of European countries. The strength, significance and domination of the former differed from country to country and changed at different points after 2015. The pro-refugee sentiments referred to such categories as solidarity, community, empathy and Christian values throughout Europe.

The photo below was one of the most significant, presented by the media in 2015, throughout Europe. The body of three-year-old Aylan Kurdi from Syria washed up on a beach in Turkey in September 2015. The photo was widely circulated in media, in social networks and became a symbol of refugee crisis and Syrian drama. Aylan Kurdi images were seen by 20 million people in 12 hours in September 2015. These photos pushed the plight of Syrian refugees to the centre of political debate across Europe $^{17}$. According to „Time” it was the most influential images of „All Time” (the most influential in 2015)

\footnotetext{
${ }^{16}$ Europe apologizes to Italy - Von der Leyen (ANSA), https://www.ansa.it/english/news/ politics/2020/04/16/europe-apologizes-to-italy-von-der-leyen_99e3767d-881 (accessed: 23.12.2020).

${ }^{17}$ A. Withnall, Aylan Kurdi images were seen by '20 million people in 12 hours', https://www. independent.co.uk/news/world/europe/refugee-crisis-aylan-kurdi-images-were-seen-20-million-people-12-hours-new-study-suggests-a6774181.html (accessed: 21.12.2020).
} 


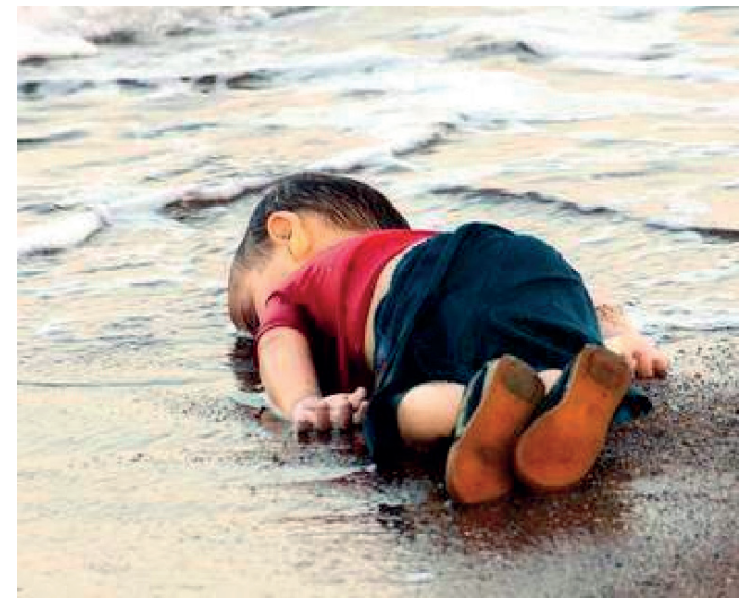

Picture 1. The picture of Aylan Kurdi from Syria (2015)

Source: Alan Kurdi's Story: Behind the most Heartbreaking Photo 2015, https://time.com/4162306/ alan-kurdi-syria-drowned-boy-refugee-crisis (accessed: 31.12.2019).

The next photos, on the other hand, portray isolation, helplessness, desperation and loneliness of the refugees.

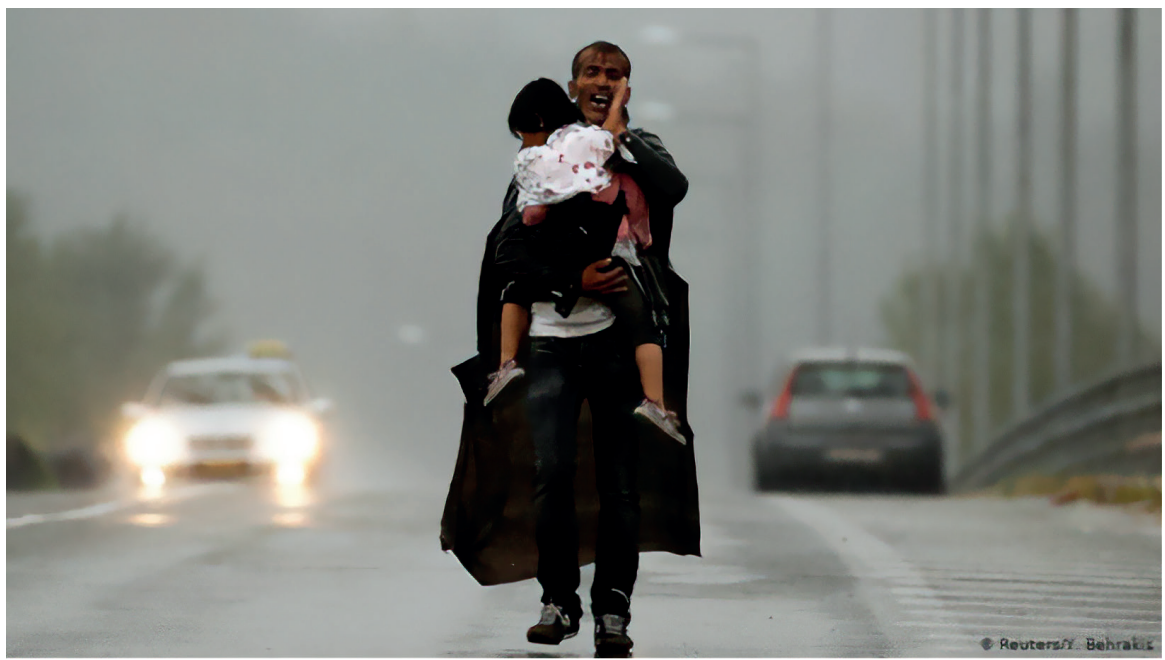

Picture 2. „Unknown home”

Source: World Refugee Day: Iconic images of the refugee crisis, https://www.dw.com/en/world-refuge e-day-iconic-images-of-the-refugee-crisis/g-39302018 (accessed: 21.01.2021).

I feel that this photo is highly significant in the sense that it is in contrast to the frequent portrayals of crouds of young people traversing Europe. Here the photographer captured the drama of a father. A Syrian man carries his daughter in the rain at the Greek-Macedonian border in Idomeni. Deutche Welle presented this photo with a title "the unknown new home". 


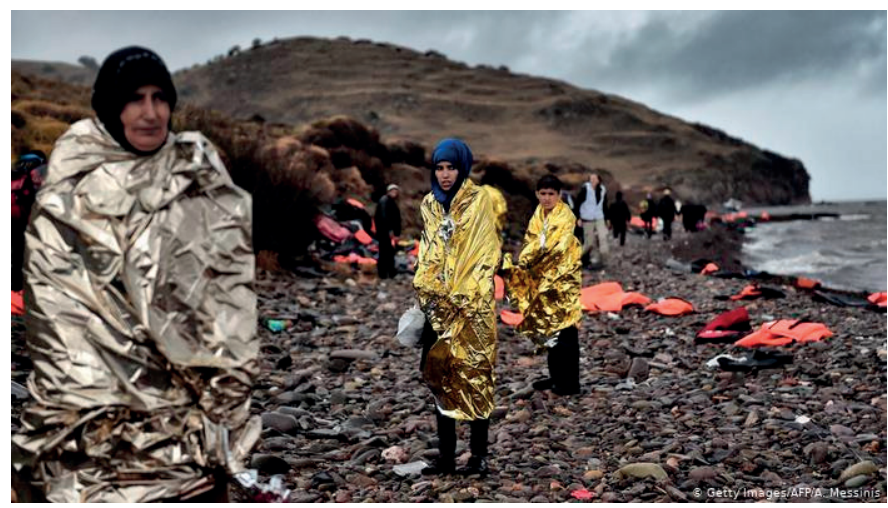

Picture 3. Together or alone?

Source: World Refugee Day...

The photograph above is one of many that portrayed distraught, lost people having managed to reach European islands. The photographs showed those, who had not lost their lives at sea. These were quite dramatic pictures of people alone, or families who had, on the one hand survived the horrors of the journey and having reached an unknown land, among thousands of other people like them, are seeking support and help. In the case of such images, journalists often made comparisons with the earlier experience of Europeans and of solidarity with others.

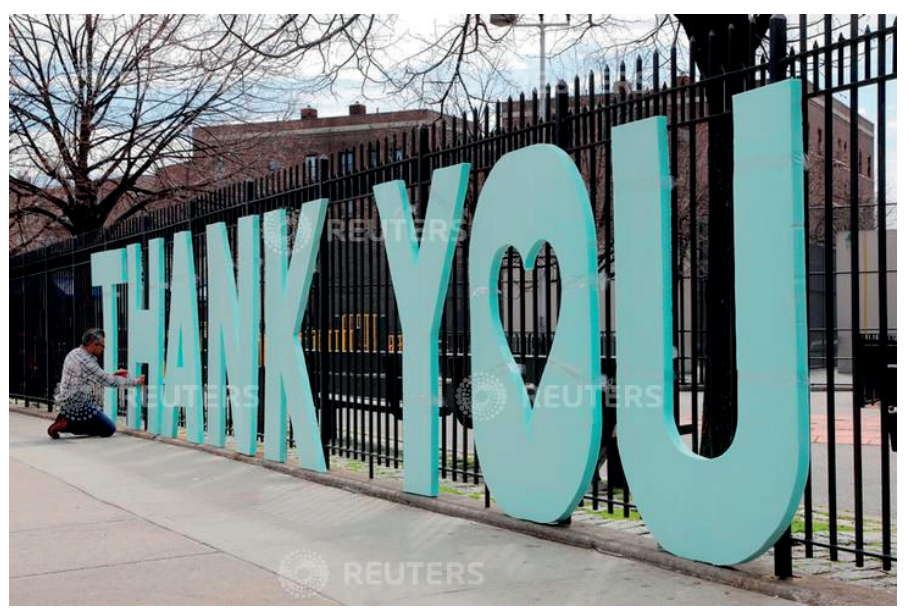

Picture 4. The significance of Thank you

Source: A. Kelly, Reuters, https://wuw.weforum.org/agenda/2020/04/coronavirus-photos-images-empty-streets-people-pandemic-COVID-19/ (accessed: 11.01.2021).

This picture became a symbol of solidarity during the COVID-19 pandemic. The "Thank You" is both an expression of obvious gratitude as well as solidarity with the medical staff. Similarly to the picture below, which expresses the drama of the pandemic as well as helplessness and support for the needy. 


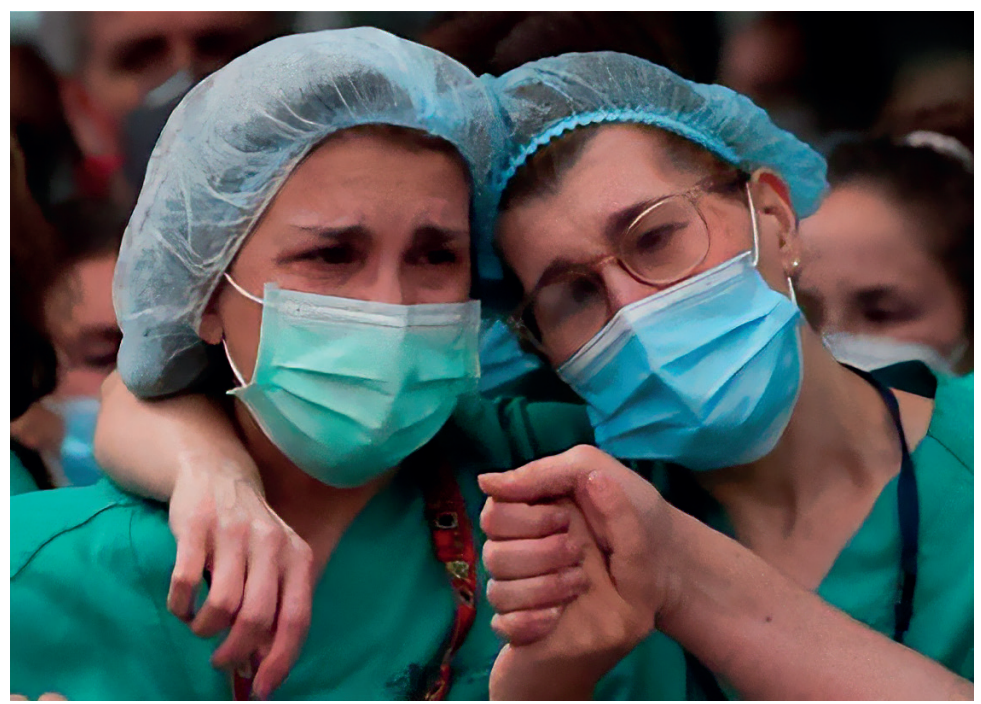

Picture 5. Solidarity with the medical staff

Source: Madrid, la gran ciudad europea con mayor exceso de mortalidad por la pandemia de coronavirus, https://www.huffingtonpost.es/entry/madrid-coronavirus-mortalidad_es_5f2581cec5b68fbfc883ce8a (accessed 1.09.2020).

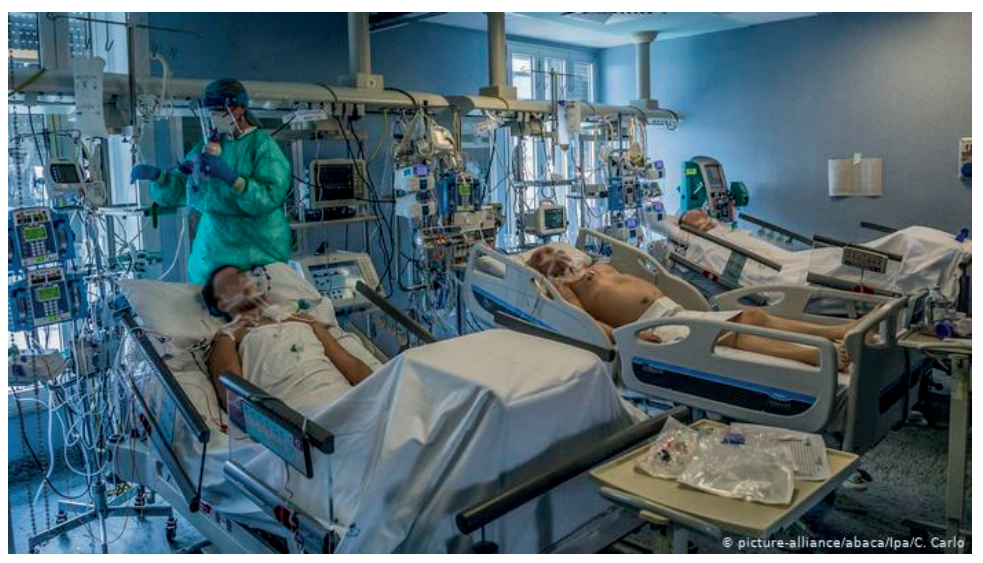

Picture 6. The daily image of hospitals

Source: Coronavirus: Short on doctors, Italy looks to migrants, https://www.du.com/en/coronavirus-short-on-doctors-italy-looks-to-migrants/a-55789791 (accessed: 24.09.2020).

The media also published photographs of very ill and dying patients. The pictures from Italy in 2020, which had been hit hardest by the pandemic, were full of images of temporary hospitals graves at cemeteries being filled at an alarming rate, were particularly hard to bear. These photographs have a very strong emotional influence and they work towards creating a certain virtual solidarity with those ill and their families. The article also describes the problems of medical staff. 


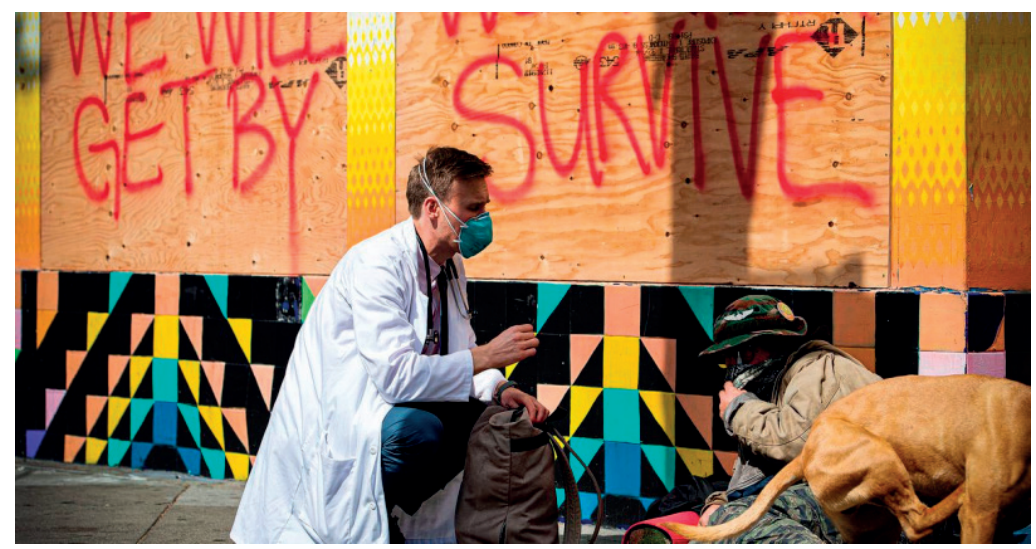

Picture 7. Solidarity with homeless

Source: C.Kim, During the COVID-19 pandemic nowhere is safe for homeless people, https://www. vox.com/2020/3/18/21183812/COVID-19-coronavirus-homeless (accessed: 24.02.2021).

As a conclusion to this part let us leave with a photograph of a doctor who is helping a homeless person during the pandemic. These types of photographs tend to serve as background images that we do not see very often. The photos of the homeless, refugee camps during the pandemic communicate a message, albeit an infrequent one, of solidarity with the 'Others' affected by the double scourge of homelessness and being a refugee.

\section{The case of Banksy at the end}

One of the symbols of the last two crises are the works of Banksy -the British street art artist. He became known for both humorous and sometimes controversial works of art. He expressed his vieus both during the migrant crisis as well as the pandemic. Banksy's works have a very pro-refugee stance. They show the need for solidarity and draw attention to the passiveness of Europeans and the EU institutions. The picture below is one of a number in which the artist touches on the migrant problem. It appeared in a place, which had itself been affected by a tragedy. Venice was flooded in 2019 on a scale that had not been seen for decades. 


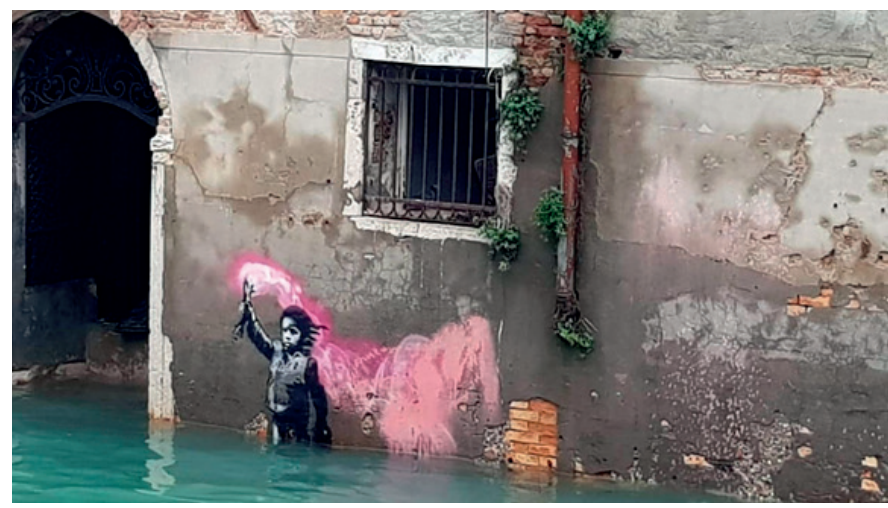

Picture 8. Banksy in Venice

Source: Academia di Belle Arti Venezia, https://www.accademiavenezia.it/eventi/aspetti-contrattuali-della-tutela-della-creativit-nella-circolazione-delle-opere-d-arte-325.html (accessed: 24.02.2021).
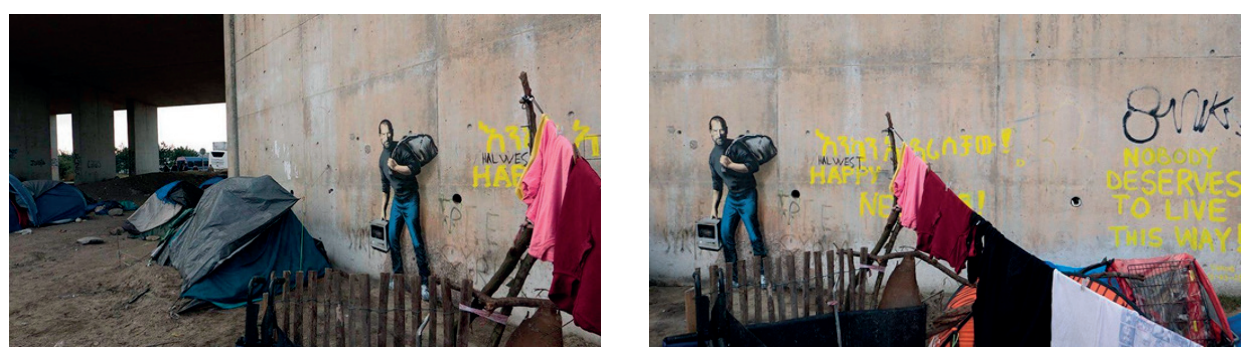

Picture 9-10. „Jungle” in Calais

Source: Banksy work in Calais "Jungle" shows Steve Job as a migrant, https://www.bbc.com/news/ world-europe-35076976 (accessed: 23.11.2018).

In a refugee camp in Calais, co-called Jungle, Banksy has created a new artwork depicting the late Steve Jobs, the founder of Apple. The artwork shous Jobs, the son of a Syrian migrant, carrying an early Apple computer and a bin bag of possessions. The work - painted on a concrete bridge in the camp - shows Jobs in his trademark black polo neck and round glasses. He appears to be carrying a bin bag full of his possessions, as if he were a migrant.

According to Banksy, The work is intended to draw attention to the benefits of migration. "We're often led to believe migration is a drain on the country's resources but Steve Jobs was the son of a Syrian migrant. Apple is the world's most profitable company, it pays over $\$ 7 \mathrm{bn}(£ 4.6 \mathrm{bn})$ a year in taxes - and it only exists because they allowed in a young man from Homs"18.

18 The camp in Calais was home to about 7,000 migrants and refugees, the majority from Syria, Afghanistan and Eritrea. While at the camp, Banksy painted several other pieces, including one based on Theodore Gericault's famous painting Raft of the Medusa, but depicting refugees waving towards a luxury yacht. 
Banksy often made reference to the pandemic in his works. The one below is particularly significant.

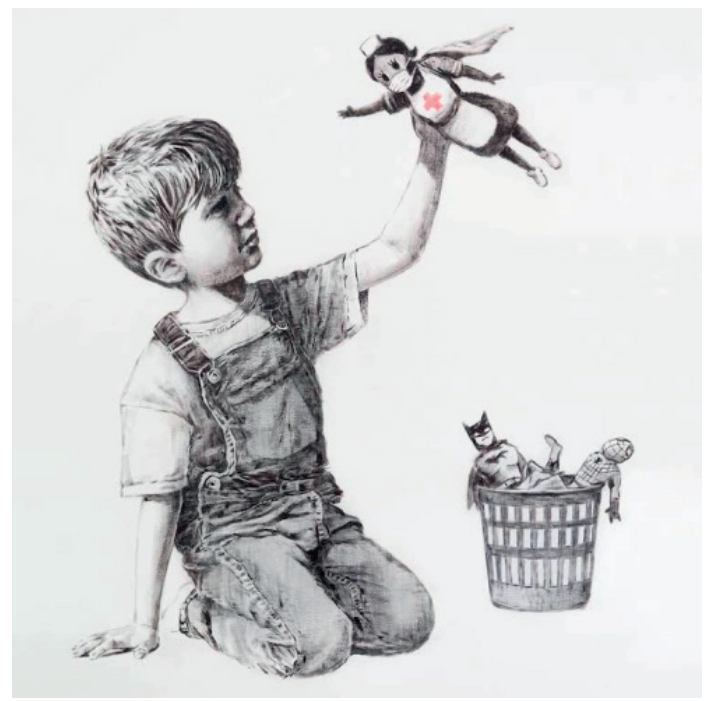

Picture 11. Banksy in the pandemic time

Source: J. Stewart, Banksy Pays Tribute to Healthcare Heroes in New Artwork Gifted to Hospital, https://mymodernmet.com/banksy-game-changer-nhs-tribute (accessed 22.02.2021).

This work, which shows a young boy kneeling down as he plays with a doll dressed as a nurse - complete with face mask - shows how these vital workers should be celebrated as heroes. This is reinforced by the fact that fictional heroes like Batman and Spiderman sit in a basket, as the boy prefers to play with his new role model. The work is almost entirely monochromatic except for the Red Cross symbol on the nurse's apron. Posted to Banksy's Instagram with the title Game Changers, the artwork was donated by the artist to Southampton General Hospital. Accompanying the artwork was a note that said, "Thanks for all you're doing. I hope this brightens the place up a bit, even if it's only black and white"19.

\section{Summary}

'Solidarity' is a category linking the two crises in this article. The photographs portraying the migration crisis take aim at solidarity with refugees and also solidarity in helping them being reinforced. Solidarity, empathy and an understanding of the Others was not something that appeared with the first arrivals. This was a lesson learned by Europeans, with varying degrees of success over many months. Some of the pictures were highly emotionally charged. They were significant both in the way we perceived

19 J. Stewart, Banksy Pays Tribute to Healthcare Heroes in New Artwork Gifted to Hospital, https://mymodernmet.com/banksy-game-changer-nhs-tribute/ (accessed: 22.02.2021). 
these people but also in the extent to which we helped them. 'Solidarity' during the COVID-19 pandemic is portrayed somewhat differently. The photographs show real signs of solidarity, sympathy, community and empathy. Emotionality is a feature of photos. Their importance increases during COVID-19 pandemic, when the audience is much more likely to seek information. However, they also want to be part of a wider community. In my opinion, the importance of pictures is increasing as media users "read" the world using pictures.

I have chosen the photographs for this article subjectively. Reception to them is strongly connected with our cultural environment. The picture of the lone father with his daughter fighting for a new life in Europe takes on a different significance in Italy, a country affected by the refugee crisis and in Poland- a country that refused to take in refugees. This is directly linked to how we treat cultural diversity, cultural differences and how we view the Others. Manuel Castells thinks that, "What we are witnessing is the historical appearance of cultural diversity than an increase in a more homogeneous global culture. What is taking place is more fragmentation than convergence. [...] Therefore, although we may personally wish that cosmopolitan culture should gradually lead to an intensification of communication between peoples and cultures, an observation of current tendencies appears to indicate something opposite to this" ${ }^{\prime 2}$.

With Castells in mind, it is worth noting that there are changes taking place in certain cultural areas that intertwine. What we are dealing with, on the one hand, is cultural globalization that refers to a defined collection of values and beliefs that are shared throughout the world. On the other there is cultural identification, a defined set beliefs and values through which particular groups recognize each other. On one plane we can find individualism, which gives us a system of values and beliefs that priorities the meeting of needs and aspirations of an individual in his/her behaviour. On the other, a sense of communality, therefore a collection of values and beliefs that position the common good above individual satisfaction of its members. Community is a sort of social system ${ }^{21}$.

The question on the significance of 'solidarity' in the time of crisis is principally a question on the values that is close to the heart of European societies and not politicians. Tomasz Sobierajski writes about Europe, that appears to be stronger than ever before, mainly because of funds and alliances. On the other, "stung by populist, dictatorial tendencies of many anti-European politicians, for whom solidarity is not a desired value [...] With this in mind they create enemies, excluding (opposite of solidarity) successive social groups, such as refugees, people of other faiths, foreigners, women, gays"22. The author poses a very pertinent question and that is whether solidarity is ceasing to be a desired value for Europeans. In analysing the photographs on the subject of the crisis events I came to the conclusion that solidarity is still a value

${ }^{20}$ M. Castells, Władza komunikacji, transl. J. Jedliński, P. Tomanek, Wydawnictuo Naukoue PWN, Warszawa 2013, p. 49.

${ }^{21}$ Ibidem.

22 T. Sobierajski, Czy potrafimy być solidarni?, „Dialog” 2019, Vol. 129, No. 3, p. 26. 
and we can find it in the public and media discourse. At the same time, as is said by Sobieralski it is something that we treat as a form of celebration, rather superficially and is not really felt. The author, bearing in mind Polish experience writes, "What can save us is solidarity in thinking of ourselves as Europeans, who in accordance with the idea of the large 'Solidarity' union see the meaning of solidarity in terms of inter-group community" 23 .

\section{References}

Academia di Belle Arti Venezia, https://wuw.accademiavenezia.it/eventi/aspetti-contrattuali-della-tutela-della-creativit-nella-circolazione-delle-opere-d-arte-325.html (accessed: 24.02.2021).

Alan Kurdi's Story: Behind the most Heartbreaking Photo 2015, https://time.com/4162306/ alan-kurdi-syria-drowned-boy-refugee-crisis (accessed: 31.12.2019).

Banksy work in Calais "Jungle" shows Steve Job as a migrant, https://www.bbc.com/news/ world-europe-35076976 (accessed: 23.11.2018).

Barthes R., Światło obrazu. Uwagi o fotografii, transl J. Trznadel, Wydawnictuo KR, Warszawa 1996.

Brandle V.K., Eisele O., Sharing Is Caring? Exploring the Relationship between Preferences for Online Participation and Support for Solidarity between EU Member States, „American Behavioral Scientist" 2019, Vol. 63, No. 4, pp. 523-537.

Całek A., Wojciech Tochman - społeczny rzecznik uchodźców. Zapiski z obserwacji netnograficznej, „Media - Biznes - Kultura” 2018, No. 1(4), pp. 71-82.

Castells M., Władza komunikacji, transl. J. Jedliński, P. Tomanek, Wydawnictwo Naukoue PWN, Warszawa 2013.

Cichocki P., Jędrkiewicz T., Zydel R., Etnografia wirtualna [in:] Badania jakościowe. Metody i narzędzia, Vol. 2, ed. D. Jemielniak, Wydaunictuo Naukoue PWN, Warszawa 2012.

Ciornei I., Recchi E., At the Source of European Solidarity: Assessing the Effects of Cross-Border Practices and Political Attitudes, „Journal of Common Market Studies” 2017, Vol. 55, Issue 3, pp. 468-485.

Coronavirus: Short on doctors, Italy looks to migrants, https://www.dw.com/en/coronavirus-short-on-doctors-italy-looks-to-migrants/a-55789791 (accessed: 24.09.2020).

Europe apologizes to Italy - Von der Leyen (ANSA), https://www.ansa.it/english/news/ politics/2020/04/16/europe-apologizes-to-italy-von-der-leyen_99e3767d-881 (accessed: 23.12.2020).

European Broadcasting Union 2020, Public Service Media are Trusted Sources of Information on COVID-19 Crisis, https://www.ebu.ch/news/2020/03/public-service-media-are-trusted-source-of-information-on-COVID-19-crisis-1 (accessed: 10.02.2021).

Global Trends Forced Displacement in 2015, http://www.unhcr.org (accessed: 23.12.2020).

Goldberg A.C., Gattermann Marquart F., Brosius A., de Vreese C.H., European solidarity in times of crisis: the role of information and media use, „West European Politics” 2021, Vol. 44(5-6), pp. 1-12.

Kelly A., Reuters, https://www.weforum.org/agenda/2020/04/coronavirus-photos-images-empty-streets-people-pandemic-COVID-19/ (accessed: 11.01.2021).

${ }^{23}$ Ibidem, p. 27. 


\section{Magdalena Ratajczak}

Lekcje z historii, rozmowa Marcina Żyły z Normanem Daviesem, „Tygodnik Pouszechny”, 20.09.2017.

Maćkiewicz J., Więcej niż tysiąc słów. Perswazyjne działanie zdjęć prasowych, „Media Biznes - Kultura" 2018, No. 1(4), pp. 25-34.

Madrid, la gran ciudad europea con mayor exceso de mortalidad por la pandemia de coronavirus,https://www.huffingtonpost.es/entry/madrid-coronavirus-mortalidad_es_5f2581cec5b68fbfc883ce8a (accessed: 1.09.2020).

Migranci, migracje. O czym warto wiedzieć, by wyrobić sobie wtasne zdanie, ed. H. Thiollet, Karakter, Kraków 2017.

Navigating the challenges of digital advertising during a global pandemic, https://www.nielsen. com/us/en/insights/article/2020/navigating-the-challenges-of-digital-advertising-during-a-global-pandemic/ (accessed: 12.01.2021).

Ratajczak M., Jędrzejczyk-Kuliniak K., Muslims and Refugees in the Media in Poland, „Global Media Journal" 2016, Vol. 6, No 1.

Sobierajski T., Czy potrafimy być solidarni?, „Dialog” 2019, Vol. 129, No. 03.

Solidarity in Europe: Citizens' Responses in Times of Crisis, eds. Ch. Lahusen, M.T. Grasso, Palgrave Macmillan, London 2018.

Stewart J., Banksy Pays Tribute to Healthcare Heroes in New Artwork Gifted to Hospital, https://mymodernmet.com/banksy-game-changer-nhs-tribute/ (accessed: 22.02.2021).

Withnall A., Aylan Kurdi images were seen by '20 million people in 12 hours', https://www. independent.co.uk/news/world/europe/refugee-crisis-aylan-kurdi-images-were-seen-20-million-people-12-hours-new-study-suggests-a6774181.html (accessed: 21.12.2020).

World Refugee Day: Iconic images of the refugee crisis, https://www.du.com/en/world-refugee-day-iconic-images-of-the-refugee-crisis/g-39302018 (accessed: 21.01.2021). 